\section{Size of Vegetation Free Area Affects Nonbearing Pecan Tree Growth}

\author{
Michael W. Smith, ${ }^{1}$ Becky S. Cheary, ${ }^{2}$ and Becky L. Carroll ${ }^{2}$ \\ Department of Horticulture and Landscape Architecture, Oklahoma State \\ University, Stillwater, OK 74078
}

Additional index words. Carya illinoinensis, Cynodon dactylon, groundcover, competition

\begin{abstract}
Newly planted pecan (Carya illinoinensis Wangenh. C. Koch cv. Kanza) trees were grown for 5 years in a bermudagrass [Cynodon dactylon (L.) Pers.] sod with vegetationfree circles $0,0.91,1.83,3.66$, or $7.32 \mathrm{~m}$ in diameter. Trees were irrigated and fertilized to minimize growth differences associated with competition from the bermudagrass. There were no differences in trunk diameter among treatments the first 2 years of the study. During the next 3 years, trunk diameter increased curvilinearly as the vegetation-free circle increased. A vegetation-free circle diameter of $1.83 \mathrm{~m}$ produced near maximum tree growth. Although trunk diameter improved slightly as the vegetation-free diameter was increased up to $7.32 \mathrm{~m}$, it was not sufficient to justify the additional expense for herbicides nor exposure of unprotected soil to erosion.
\end{abstract}

Vegetative groundcover surrounding trees competes for nutrients (Bould and Jarrett, 1962; Goff et al., 1991; Smith et al., 1959; Worley and Carter, 1972) and water (Patterson et al., 1990; Ware and Johnson, 1958), and in some instances may be allelopathic (Friedman and Horowitz, 1970; Meissner et al., 1989; Menges, 1987; Smith et al., 2001; Wolf and Smith, 1999). Tree growth during orchard establishment can be increased by maintaining a vegetation-free area surrounding the tree (Foshee et al., 1995; Patterson et al., 1990; Patterson and Goff, 1994; Smith et al., 2002; Wolf and Smith, 1999). Cultivation (Foshee et al., 1997; Merwin et al., 1994; Patterson et al., 1990; Patterson and Goff, 1994; Smith et al., 1959), herbicides (Foshee et al., 1997; Merwin et al., 1994; Norton and Storey, 1970; Patterson et al., 1990; Patterson and Goff, 1994), or various mulch materials (Foshee et al., 1996; Merwin et al., 1994; Smith et al., 2000) have been used to control vegetation that interferes with growth. Cultivation is normally considered undesirable since it increases soil erosion, causes soil structure loss, and frequently results in tree injury. Mulches are probably the most effective means for increasing tree growth since they not only suppress vegetation, but also reduce soil moisture loss (Smith et al., 2000). However, mulch materials can be difficult to obtain, and mulching is labor-intensive. Herbicides are widely accepted in modern agriculture as an effective and relatively inexpensive tool to control unwanted vegetation. One question that often arises when establishing an orchard is the optimum size of the vegetation-free area around trees. This study evaluates the impact of vegetation-free areas on growth and establishment of pecan trees in a bermudagrass sod.

Received for publication 20 Jan. 2005. Accepted for publication $13 \mathrm{Feb}$. 2005. Approved for publication by the Oklahoma Agriculture Experiment Station, Stillwater.

${ }^{1}$ Regents professor.

${ }^{2}$ Research technician. most water, but during the later years of the study treatments with the largest trees used the most water).

Treatments were vegetation-free circles surrounding the trees that were $0,0.91,1.83$, 3.66 , or $7.32 \mathrm{~m}$ in diameter. Each treatment was replicated 12 times in a randomized complete block design. Trunk diameters $30 \mathrm{~cm}$ above the soil were measured annually while the trees were dormant. Growth data were analyzed by regression analysis.

\section{Results and Discussion}

Trunk diameter was not affected by treatment during the first 2 years of the study (Fig. 1). The third through fifth years following transplanting there was a significant curvilinear relationship between the size of the vegetation-free circle and trunk diameter. Trunk diameters were $8 \%$ to $15 \%$ larger in the third through the fifth growing seasons with a $0.91 \mathrm{~m}$ vegetation-free circle compared to no vegetation-free zone. Trunk diameters substantially increased in size up to a $1.83 \mathrm{~m}$ diameter vegetation-free circle, and then trunk size increments were much less but continued to improve up to $7.32 \mathrm{~m}$ in diameter.

Results of this study were similar to those from a study using a tall fescue (Festuca arundinacae Shreb.) sod in that the shape of the response curve was similar (Smith et al., 2002), but the magnitude of growth suppression was much greater by tall fescue than bermudagrass. Trunk diameters of trees surrounded by fescue were up to $260 \%$ smaller after three growing seasons than those with vegetation control. Bermudagrass surrounding the trees only reduced trunk diameter up to $27 \%$ by the end of the third growing season (Fig. 1). At the end of the fifth growing season bermudagrass suppressed trunk diameter from $8 \%$ to $27 \%$ depending on the vegetation-free circle size. The studies using bermudagrass or tall fescue sods were located within $200 \mathrm{~m}$ of each other and were managed similarly; however, there were differences in the two studies. The most notable difference was tree size and age at transplanting. In the study with tall fescue, trees were $0.3 \mathrm{~m}$ tall, 5-month-old container grown seedlings (Smith et al., 2002), and in the study with bermudagrass trees were 1.5 to 1.8 m tall, 3-year-old bare root 'Kanza' on Giles rootstock. Fescue may be more detrimental to tree growth than bermudagrass, but this is unclear. In a container study, bermudagrass and tall fescue suppressed tree growth similarly (Smith et al., 2001). Initial tree size or age, or other differences in the two studies may affect initial growth rate more than sod species. Both studies agree that, regardless of the sod species, tree growth is suppressed if the vegetation is not controlled surrounding the tree.

Results of this study suggest that a $1.83 \mathrm{~m}$ diameter vegetation-free circle produced near maximum tree growth during the first five growing seasons. Larger areas improved tree growth slightly, but not enough to justify the added expense and potential erosion problems associated with larger vegetation-free areas. A study with tall fescue also found that a $1.83 \mathrm{~m}$ 


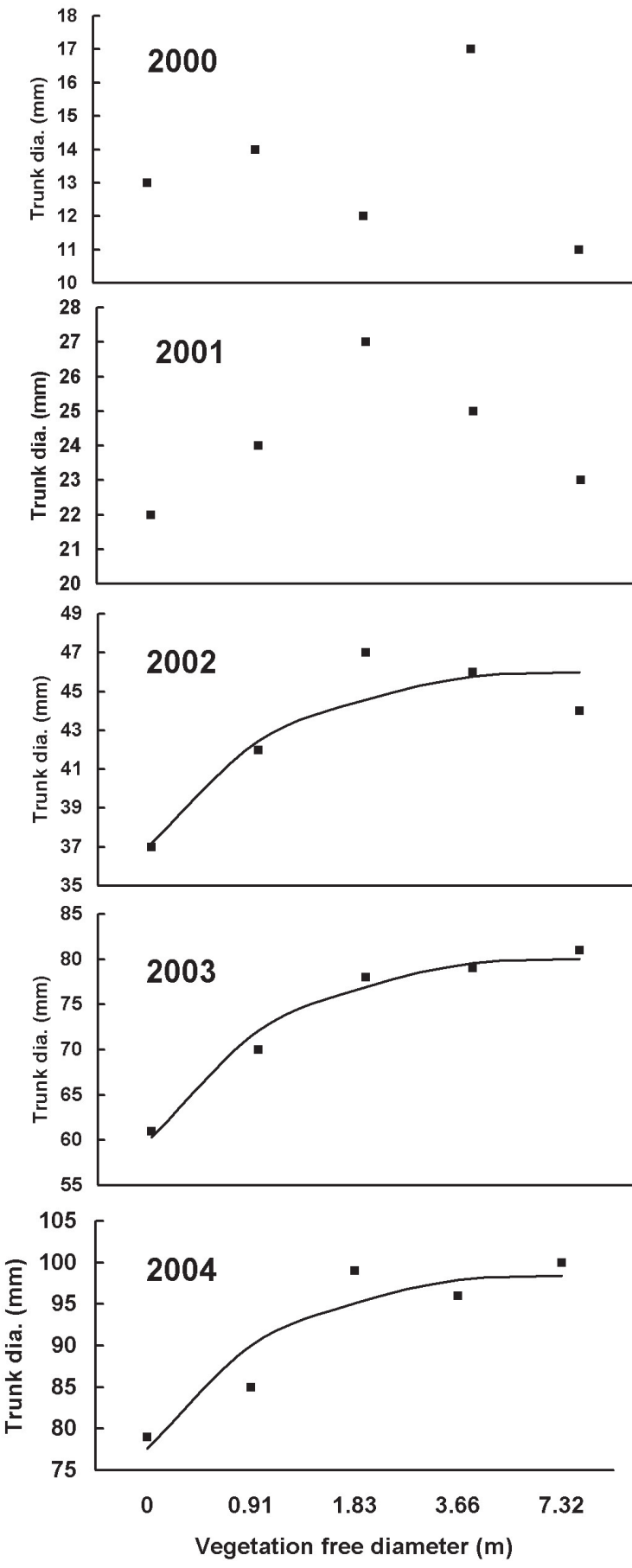

Fig. 1. The relationship between size of a vegetation-free circle surrounding pecan trees and trunk diameter. Treatments began at transplanting and continued through the fifth growing season (2000 through 2004). Boxes represent the mean of 12 replications per treatment. Lines show the significant relationship between diameter of the vegetation-free circle and trunk diameter. In 2000 and 2001 there were no significant relationships. In 2002, 2003, and 2004 there were significant curvilinear relationships. Equations and coefficients of determination are $\mathrm{y}=45.99-8.783 \times \mathrm{e}^{-\mathrm{x}}, r^{2}=0.84^{* *} ; \mathrm{y}=80.09-19.784 \times \mathrm{e}^{-\mathrm{x}}, r^{2}$ $=0.97^{* * *}$, and $\mathrm{y}=98.44-20.884 \mathrm{e}^{-\mathrm{x}}, r^{2}=0.86^{* *}$ for 2002,2003 and 2004, respectively; where, $\mathrm{y}=$ trunk diameter in $\mathrm{mm}, \mathrm{e}=$ the constant 2.718 , and $\mathrm{x}=$ the vegetation-free diameter in meters. Coefficients of determination are significant at $1 \%(* *)$ or $0.1 \%(* * *)$. diameter vegetation-free circle produced near maximum tree growth rates.

\section{Literature Cited}

Bould, C. and R.M. Jarrett. 1962.

The effect of cover crops and NPK fertilizers on growth, crop yield and leaf nutrient status of young dessert apple trees. J. Hort. Sci. 37:58-82.

Foshee, W.G., W.D. Goff, M.G. Patterson, and D.M. Ball. 1995. Orchard floor crops reduce growth of young pecan trees. HortScience 30:979-980.

Foshee, W.G., W.D. Goff, K.M. Tilt, and J.D. Williams. 1996. Organic mulches increase growth of young pecan trees. HortScience 31:811-812.

Foshee, III, W.G., , R.W. Goodman, M.G. Patterson, W.D Goff and W.A. Dozier, Jr. 1997. Weed control increases yield and economic returns from young 'Desirable' pecan trees. J. Amer. Soc. Hort. Sci. 122:588-593.

Friedman, T. and M. Horowitz. 1970. Phytotoxicity of subterranean residues of three perennial weeds. Weed Res. 10:382-385.

Goff, W.D., M.G. Patterson, and M.S. West. 1991. Orchard floor management practices influence elemental concentrations in young pecan trees. HortScience 26:1379-1381.

Meissner, R., P.C. Nel, and E.A. Beyers. 1989.Allelopathic effect of Cynodon dactylon infested soil on early growth of certain crop species. Applied Plant Sci. 3:125-126.

Menges, R.M. 1987. Allelopathic effects of Palmer amaranth (Amaranthus palmeri) and other plant residues in soil. Weed Sci. 35:339-347.
Merwin, I.A., W.C. Stiles, and H.M. van Es. 1994 Orchard groundcover management impacts on soil physical properties. J. Amer. Soc. Hort. Sci. 119:216-222.

Norton, J.A. and J.B. Storey. 1970. Effect of herbicides on weed control and growth of pecan trees. Weed Sci. 18:522-524.

Patterson, M.G. and W.D. Goff. 1994. Effects of weed control and irrigation on pecan (Carya illinoinensis) growth and yield. Weed Technol. 8:717-719.

Patterson, M.G., G. Wehtje, and W.D. Goff. 1990.Effects of weed control and irrigation on the growth of young pecans. Weed Technol. 4:892-894.

Smith, C.L., O.W. Harris, and H.E. Hammar. 1959. Comparative effects of clean cultivation and sod on tree growth, yield, nut quality, and leaf composition of pecan. J. Amer. Soc. Hort. Sci. 75:313-321.

Smith, M.W. 1991. Pecan nutrition, p. 152-158. In: B.W. Wood and J.A. Payne (eds.). Pecan husbandry: Challenges and opportunities. U.S. Dept. Agr., Agr. Res. Serv.-96.

Smith, M.W., B.L. Carroll, and B.S. Cheary. 2000. Mulch improves pecan tree growth during orchard establishment. HortScience 35:192-195.

Smith, M.W., B.S. Cheary, and B.L. Carroll. 2002. Fescue sod suppresses young pecan tree growth. HortScience 37:1045-1048.

Smith, M.W., M.E. Wolf, B.S. Cheary, and B.L. Carroll. 2001. Allelopathy of bermudagrass, tall fescue, redroot pigweed and cutleaf evening primrose on pecan. HortScience 36:1047-1048.

Ware, L.M. and W.A. Johnson. 1958. Certain relationships between fertilizer and cultural practices, nitrate and moisture content of the soil, and responses of pecan trees. Proc. S.E. Pecan Growers Assn. 51:10-17.

Wolf, M.E. and M.W. Smith. 1999. Cutleaf evening primrose and Palmer amaranth reduce growth of nonbearing pecan trees. HortScience 34:1082-1084

Worley, R.E. and R.L. Carter. 1972. Effect of four management systems on parameters associated with growth and yield of pecan. J. Amer. Soc. Hort. Sci. 98:541-546. 